\title{
Corn seed inoculation with Azospirillum brasilense in different nitrogen fertilization management
}

\author{
Mauricio Vicente Alves ${ }^{1} \oplus$, Cristiano Nunes Nesi ${ }^{1} \oplus$, Gabriela Naibo ${ }^{1} \oplus$, Matheus Henrique Barreta ${ }^{1} \oplus$,

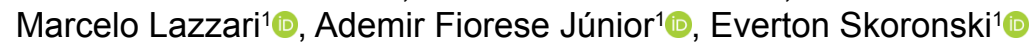

\footnotetext{
${ }^{1}$ Santa Catarina Western University, Xanxerê, SC, Brazil. E-mail: mauricio.alves@unoesc.edu.br; cristiano.nesi@unoesc.edu.br; naibogabriela@gmail.com; barreta_222@hotmail.com; marcelo.lazzarigba@hotmail.com; junior_fiorese2@hotmail.com; everton.skoronski@udesc.br
}

ABSTRACT: Seed inoculation with Azospirillum brasilense might be an interesting alternative to reduce the nitrogen demand applied to plants and to enhance the effect of these fertilizers. This study aimed to evaluate the components of maize crops and its response to inoculation with $A$. brasilense associated with sowing and top cover nitrogen fertilization. A completely randomized block experimental design was used, and the tests were carried out in two crop years. The treatments in the first crop year were: $\mathrm{BF}+\mathrm{CF}:\{$ nitrogen base fertilization $(\mathrm{BF})+$ cover fertilization $(\mathrm{CF})\} ; \mathrm{BF}+\mathrm{Bl}:\{\mathrm{BF}+\mathrm{A}$. brasilense bacterium inoculation $(\mathrm{BI})\} ; \mathrm{BF}$ $+\mathrm{BI}+\mathrm{CF} ; \mathrm{BI} ; \mathrm{BI}+\mathrm{CF}$ and $\mathrm{NFI}$ : no fertilization or inoculation\}. The same treatments were tested in the second crop year, and the CF was added. The tests were carried out in the field, in the municipality of Abelardo Luz - SC - Brazil. The climate is humid mesothermal with hot summers and cold winters (Cfa). The following parameters were evaluated: plant height, leaf and grain nitrogen, yield, thousand-grains weight, and grain moisture. The inoculation of $A$. brasilense associated with cover fertilization could be an alternative to reduce the demand for $\mathrm{N}$, including an increase in productivity. The use of $A$. brasilense without $\mathrm{N}$ fertilization provided an increase in crop yield.

Key words: biological nitrogen fixation; diazotrophic bacteria; symbiosis; Zea mays L.

\section{Inoculação de sementes de milho com Azospirillum brasilense em diferentes manejos de adubação nitrogenada}

RESUMO: A inoculação de sementes com Azospirillum brasilense pode ser uma opção interessante para reduzir a quantidade de nitrogênio aplicada nas plantas e potencializar o efeito desses fertilizantes. $O$ objetivo deste estudo foi avaliar os componentes do cultivo de milho e sua resposta à inoculação com $A$. brasilense associada à adubação nitrogenada na semeadura e cobertura superior. $O$ delineamento experimental foi em blocos casualizados e realizados em dois anos agrícolas. Os tratamentos no primeiro ano: $\mathrm{BF}+\mathrm{CF}$ : \{adubação nitrogenada de base $(\mathrm{BF})+$ adubação de cobertura $(\mathrm{CF})\} ; \mathrm{BF}+\mathrm{BI}:\{\mathrm{BF}+$ inoculação da bactéria $A$. brasilense $(\mathrm{BI})\} ; \mathrm{BF}+\mathrm{BI}+\mathrm{CF} ; \mathrm{Bl} ; \mathrm{BI}+\mathrm{CF}$ and $\mathrm{NFI}$ : \{sem adubação e sem inoculação\}. No segundo ano foram os mesmos tratamentos e adicionado o CF. Os estudo foi a campo no municio de Abelardo Luz - SC - Brasil. O clima é mesotérmico úmido com verões quentes e invernos frios (Cfa). Foram avaliados: altura de plantas, nitrogênio na folha e no grão, produtividade, peso de mil grãos e umidade do grão. A inoculação de $A$. brasilense associada à adubação de cobertura, pode ser uma alternativa para reduzir a demanda de $\mathrm{N}$, incluindo um aumento na produtividade. $\mathrm{O}$ uso de $A$. brasilense sem adubação de $\mathrm{N}$ proporcionou aumento no rendimento da cultura.

Palavras-chave: fixação biológica de nitrogênio; bactérias diazotróficas; simbiose; Zea mays L. 


\section{Introduction}

Maize is one of the main cereals cultivated in the world, presenting a production of $1,075.61$ million tons in $2017 / 2018$. Brazil is the world's third-largest maize producer (82 million tons), following the United States of America (371.1 million tons) and China (259.07 million tons) (UDSA, 2019). Although most of the national production was initially cultivated to supply Brazilian demand, the animal feed industries are currently the leading destination for the crop (Conab, 2018). The increase in crop productivity in Brazil is due to better soil management (in terms of soil chemistry, physics, and biology), adequate fertilization, changes in the plant arrangement and use of cultivars with high genetic potential. On the other hand, despite Brazil being a large fertilizer market, it is fragile due to its strong dependence on importation. Therefore, it is crucial to find alternatives for more efficient use of fertilizers. In this context, some microorganisms, such as atmospheric nitrogen-fixing bacteria and plant growth-promoting bacteria, among others, might be a cost-effective and local alternative (Chalk, 2016).

Even though nitrogen is essential to maize growth and production, this nutrient has problems associated with its use such as a high cost, low absorption by plants, and potential environmental issues. In this sense, the inoculation of seeds with rhizobacteria such as Azospirillum brasilense may be a promising alternative. This includes a reduction in the number of seeds applied and potentiates the effect of nitrogenous fertilizers. These diazotrophic microorganisms are responsible for the biological fixation of atmospheric nitrogen and can therefore complement the amount of nutrients required by plants (Picazevicz et al., 2017). Another benefit of rhizobacteria is acting as plant growth promoters through various mechanisms such as phosphate solubilization, phytohormone and siderophore production, as well as pathogen and insect biocontrol (Hungria et al., 2010; Fukami et al., 2018; Bulegon et al., 2019).

The last 25 years have seen a renewed importance in the potentialities of rhizospheric or free-living bacteria of the Azospirillum genus, which are atmospheric nitrogen fixators and growth promoters (Chalk, 2016). Ladha et al. (2016) assessed the nitrogen utilization in major cereal crops and estimated different fertilizer or soil sources of 29,38 , and $25 \mathrm{~kg} \mathrm{~N} \mathrm{ha}^{-1}$ year ${ }^{-1}$ for corn, rice, and wheat, respectively. Hence, inoculation of diazotrophic bacteria can be a biotechnological and sustainable alternative in terms of nitrogen requirements for the plants. Additionally, they can produce auxins, which are substances responsible for plant growth stimulation, leading to a lower nitrogen utilization in these crops (Fukami et al., 2018).

Despite this interest, our knowledge on applying $A$. brasilense to assist nitrogen fixation in maize crops is largely based on minimal data. Thus, the aim of this study was to evaluate the effect of inoculating Azospirillum brasilense and different forms of mineral nitrogen application on maize crops.

\section{Materials and Methods}

The experiment was carried out in the municipality of Abelardo Luz $[-266,480651,-52,408425]$ (Southern Brazil), during the 2013/2014 and 2014/2015 crop years. The region's soil is classified as reddish Bruno Oxisol (Santos et al., 2018). The climate of the area is humid with hot summers and cold winters ( $\mathrm{Cfa}$ ) according to the Köppen classification (Alvares et al., 2013), with an average annual temperature of $18.7^{\circ} \mathrm{C}$. The soil chemical characteristics before installing the experiment were determined according to the methods described in Tedesco et al. (1995), and are shown in Table 1.

The $\mathrm{pH}$ was within the ideal range for cultivating corn. According to the Comissão de Química e Fertilidade do Solo $-R S / S C$ (2004), the $\mathrm{pH}$ for decision-making is 5.5 , and the reference is 6.0. The soil organic matter concentration (Table 1) accounted for average values (2.6 - 5.0\%), the phosphorus content $(P)$ was high $\left(9.1-18.0 \mathrm{mg} \mathrm{dm}^{-3}\right)$, the potassium was very high (>120 mg dm $\mathrm{m}^{-3}$ ), and the presence of $\mathrm{Ca}$ and $\mathrm{Mg}$ were also considered high ( $>4.0 \mathrm{c}_{\text {molc }} \mathrm{dm}^{-3}$ and $>1.0 \mathrm{c}_{\text {molc }} \mathrm{dm}$ 3 , respectively). These classifications are suggested by the Comissão de Química e Fertilidade do Solo - RS/SC (2004), which leads us to conclude that this soil was considered ideal for cultivation.

The treatments were arranged in a randomized block design with six replications in the first year and four replications in the second crop year. Six treatments were evaluated in the first crop year: $B F+C F-$ base nitrogen fertilization $(B F)$ at a dose of $50.4 \mathrm{~kg} \mathrm{ha}^{-1}$ and nitrogen cover fertilization (CF) at $99.6 \mathrm{~kg} \mathrm{ha}^{-1} ; \mathrm{BF}+\mathrm{BI}$ - base nitrogen fertilization at a dose of $50.4 \mathrm{~kg} \mathrm{ha}^{-1}$ and $A$. brasilense bacterial inoculation (BI) at a

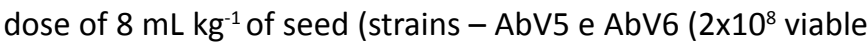
cells $\left.\mathrm{mL}^{-1}\right) ; \mathrm{BF}+\mathrm{BI}+\mathrm{CF}$ - base nitrogen fertilization dose of 50.4 $\mathrm{kg} \mathrm{N}$ and $A$. brasilense bacterium inoculation at a dose of 8 $\mathrm{mL} \mathrm{kg}{ }^{-1}$ of seed plus nitrogen cover fertilization at a dose of $99.6 \mathrm{~kg} \mathrm{ha}^{-1} ; \mathrm{BI}-A$. brasilense bacterium inoculation at the dose of $8 \mathrm{~mL} \mathrm{~kg}^{-1}$ of seed; BI+CF - Bacterium inoculation at a dose of $8 \mathrm{~mL} \mathrm{~kg}{ }^{-1}$ of seed and nitrogen cover fertilization at a dose of $99.6 \mathrm{~kg} \mathrm{ha}^{-1}$; and NFI - no fertilization or bacteria inoculation. The previous tests were repeated in the second

Table 1. Soil fertility analysis before experiment implementation. The results are expressed as an average of five samples collected and analyzed in 2013.

\begin{tabular}{|c|c|c|c|c|c|c|c|c|c|c|}
\hline \multicolumn{2}{|c|}{ Content } & \multicolumn{2}{|c|}{$\mathrm{pH}$} & \multirow{3}{*}{$\begin{array}{c}\text { O.M. } \\
\left(\mathrm{g} \mathrm{kg}^{-1}\right)\end{array}$} & \multicolumn{6}{|c|}{ Concentration } \\
\hline \multirow{2}{*}{$\begin{array}{l}\text { Deep } \\
(\mathrm{cm})\end{array}$} & \multirow{2}{*}{$\begin{array}{c}\text { Clay } \\
\left(\mathrm{g} \mathrm{kg}^{-1}\right)\end{array}$} & Water & SMP & & $\mathbf{P}$ & $K$ & $\mathrm{Ca}$ & $\mathrm{Mg}$ & Al & $(\mathrm{H}+\mathrm{Al})$ \\
\hline & & 1:1 & $1.5: 1$ & & \multicolumn{2}{|c|}{$\left(\mathrm{mg} \mathrm{dm}^{-3}\right)$} & \multicolumn{4}{|c|}{$\left(\mathrm{cmol}_{\mathrm{c}} \mathrm{dm}^{-3}\right)$} \\
\hline $0-20$ & 450 & 5.6 & 6.2 & 41.5 & 16.65 & 332.35 & 6.02 & 3.24 & 0 & 4.89 \\
\hline
\end{tabular}

*SMP: Shoemaker, Maclean \& Pratt buffer; O.M.: organic matter. 
crop year, including an additional treatment: CF - nitrogen cover fertilization of $150 \mathrm{~kg} \mathrm{ha}^{-1}$, divided equally in V4 and V8 stages. All treatments received potassium cover fertilization of $100 \mathrm{~kg} \mathrm{ha}^{-1}$ of Potassium Chloride $(\mathrm{KCl})$ at the V6 stage in the two crop years. We used $314 \mathrm{~kg} \mathrm{ha}^{-1}$ of triple superphosphate as a phosphorous source, applied in furrowing with the seed during the two crop years. The treatments that received nitrogen cover fertilization (urea) were equally divided into the V4 and V8 phenological stages. The fertilization dosage was calculated according to Comissão de Química e Fertilidade do Solo - RS/SC (2004), and the soil analysis was carried out according to Table 1 . The microbiological inoculant contained bacteria of the $A$. brasilense genus at a concentration of 200 million bacteria $\mathrm{mL}^{-1}$ and at a dose of $100 \mathrm{~mL} \mathrm{ha}^{-1}$. Inoculation was carried out manually and prior to the sowing. It was accomplished by mixing the inoculant liquid and the seed in the dosage recommended by the manufacturer.

The experimental area in the first crop year was $1200 \mathrm{~m}^{2}$ composed of 36 plots. Each plot consisted of 8 rows 10 meters long, spaced 0.50 meters. The useful area of each parcel was $16 \mathrm{~m}^{2}$, as the four outer lines and one meter of the edges were neglected due to the boundary effect. The total experimental area in the second crop year was $280 \mathrm{~m}^{2}$ composed of 28 plots, each plot consisting of four $5 \mathrm{~m}$ lines with $0.50 \mathrm{~m}$ spacing between them. The two perimeter lines and $0.5 \mathrm{~m}$ from the edge were neglected due to the boundary effect, totalling a useful area of $4 \mathrm{~m}^{2}$ in each plot.

The experiment was set up in the first crop year (November $22^{\text {nd }}, 2013$ ), with maize sown under a no-tillage farming system. The seed used was P1630 Hx, a simple, early hybrid, which is already sold with active ingredient treatment (25 $\mathrm{g} \mathrm{L}^{-1}$ Diphenoconazole $+25 \mathrm{~g} \mathrm{~L}^{-1}$ Fludioxonil and 262.5 $\mathrm{g} \mathrm{L}^{-1}$ Tiametoxam ) + (Fipronil $250 \mathrm{~g} \mathrm{~L}^{-1}+$ Piraclostrobin $25 \mathrm{~g} \mathrm{~L}^{-1}+$ Thiophanate-methyl $\left.225 \mathrm{~g} \mathrm{~L}^{-1}\right)$. An initial population of 80,000 plants ha ${ }^{-1}$ was defined. A physiological insecticide containing the active ingredient Teflubenzuron at a dose of $100 \mathrm{~mL} \mathrm{per} \mathrm{ha-1}^{-1}$ was applied before sowing and drying to control the caterpillars remaining in the residuals from the previous crop. Moreover, $2 \mathrm{~L} \mathrm{ha} \mathrm{a}^{-1}$ of active ingredient Glyphosate $\left(480 \mathrm{~g} \mathrm{~L}^{-1}\right)$ was used for desiccation. The second crop year started on August 20 2014. Desiccation was previously accomplished before beginning the experiment. In this case, the same herbicide as in the previous year was applied. The active ingredient Espinosade $480 \mathrm{~g} \mathrm{~L}^{-1}$ at a dose of $80 \mathrm{~mL} \mathrm{ha}^{-1}$ was employed to control caterpillars. Maize sowing occurred on September $23^{\text {rd }}, 2014$, under a no-tillage farming system with the same variety and population of plants used in the preceding year.

The analytical determinations in the 2013/2014 season were: plant height at 45 and 90 days after planting; leaf nitrogen determination at 90 days, using the opposite leaf below the ear (flag leaf); grain nitrogen determination; crop yield, ear length, number of rows, one thousand grain weight and grain moisture at harvest. Plant height was determined by measuring 10 random plants in the plot useful area based on the distance from the soil surface to the leaf edge. Next, 10 leaves were collected after 90 days for leaf nitrogen determination through the Kjeldahl digestion method according to Tedesco et al. (1995). This method was also used for determining nitrogen in the grain. The thousand-grain weight was determined using a precision scale $(0.01 \mathrm{~g})$. Crop yield was determined by collecting the plant ears from the useful plot area and adjusting the moisture to $14 \%$.

The determinations carried out in 2014/2015 were also evaluated as described in the previous year: crop yield, ear length, number of rows, thousand-grain weight and nitrogen in the grain, and seed moisture at harvest. Harvesting was performed manually, harvesting all ears of the useful area.

Data were subjected to analysis of variance and means compared by the Scott-Knott test at $5 \%$ significance. All analyses were performed using the R program (R Core Team, 2019).

\section{Results and Discussion}

Plant height (Table 2) in the first crop year at 45 days of the cycle shows that the treatments that received base treatment + nitrogen cover fertilization and base treatment + bacteria inoculation ( $\mathrm{BF}+\mathrm{CF}$ and $\mathrm{BF}+\mathrm{BI}+\mathrm{CF}$ ) presented higher plants than the other treatments. The lowest heights were observed in the treatments without nitrogen fertilization ( $\mathrm{BI}$ and $\mathrm{NFI}$ ). However, no significant difference between treatments was observed when the plant height at 90 days of the cycle was evaluated. In a study by Cavallet et al. (2000), the authors tested the inoculation of Azospirillum spp., the application of mineral nitrogen (70 kg ha-1 using ammonium sulfate) at sowing and mineral nitrogen in the coverage $\left(70 \mathrm{~kg} \mathrm{ha}^{-1}\right.$ using urea). The authors did not identify a significant difference in the height of maize plants at 90 days after sowing, thus corroborating our results. The same authors also claim that this response is essential because it nullifies the adverse effect associated with tipping.

Ear length was influenced by nitrogen fertilization in the two crop years studied (Table 3 ). The average value of the treatments that received nitrogen cover fertilization $(\mathrm{BF}+\mathrm{CF}, \mathrm{BF}+\mathrm{BI}+\mathrm{CF}$, and $\mathrm{BI}+\mathrm{CF}$ ) was significantly superior to the treatments which did not receive cover fertilization ( $\mathrm{BF}+\mathrm{BI}, \mathrm{NI}$, and $\mathrm{NFI}$ ). This significant increase in ear length between treatments increased the grain crop production per ear, which led to an increase in

Table 2. Height of maize plants at 45 days and 90 days after emergence in response to seed inoculation with Azospirillum brasilense and nitrogen fertilization at sowing and cover, 2013/2014 crop year.

\begin{tabular}{ccc}
\hline Treatment & $\begin{array}{c}\text { Height after } \\
\mathbf{4 5} \text { days }(\mathrm{m})\end{array}$ & $\begin{array}{c}\text { Height after } \\
\mathbf{9 0} \text { days }(\mathrm{m})\end{array}$ \\
\hline $\mathrm{BF}+\mathrm{CF}$ & $1.40 \mathrm{a}$ & $1.65 \mathrm{a}$ \\
$\mathrm{BF}+\mathrm{BI}$ & $1.02 \mathrm{~b}$ & $1.55 \mathrm{a}$ \\
$\mathrm{BF}+\mathrm{BI}+\mathrm{FC}$ & $1.38 \mathrm{a}$ & $1.60 \mathrm{a}$ \\
$\mathrm{BI}$ & $0.74 \mathrm{c}$ & $1.43 \mathrm{a}$ \\
$\mathrm{BI}+\mathrm{CF}$ & $1.09 \mathrm{~b}$ & $1.53 \mathrm{a}$ \\
$\mathrm{NFI}$ & $0.73 \mathrm{c}$ & $1.34 \mathrm{a}$ \\
$\mathrm{CV}(\%)$ & 9.2 & 11.49 \\
\hline
\end{tabular}

* Means followed by the same letter in the column do not differ from each other by the Scott-Knott test at $5 \%$ probability. $\mathrm{BF}+\mathrm{CF}=\mathrm{Base}+$ cover fertilization; $\mathrm{BF}+\mathrm{BI}=\mathrm{Base}$ Fertilization + Inoculation; $\mathrm{BF}+\mathrm{BI}+\mathrm{CF}=\mathrm{Base}+$ cover fertilization + Inoculation; $\mathrm{BI}=\mathrm{In}$ oculation; $\mathrm{BI}+\mathrm{CF}=$ Inoculation + cover fertilization; $\mathrm{NFI}=$ no fertilization or inoculation. 
Table 3. Corn ear length, number of rows per ear, 1000 grain mass and yield $\left(\mathrm{kg} \mathrm{ha}^{-1}\right)$ in the two crop years in response to seed inoculation with Azospirillum brasilense, and nitrogen fertilization at sowing and cover.

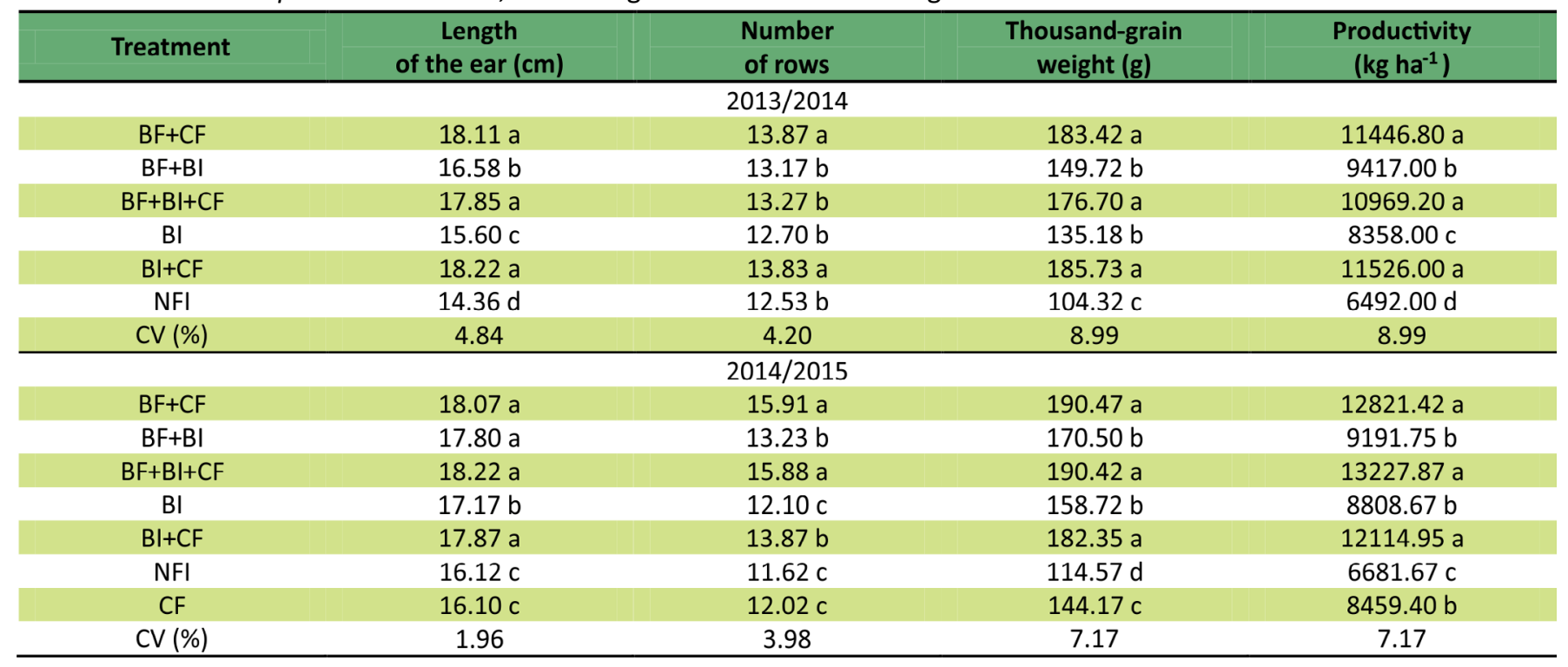

* Means followed by the same letter in the row do not differ from each other in the first crop year and averages followed by the same letter in the column do not differ from each other by the Scott-Knott test at $5 \%$ probability. $\mathrm{BF}+\mathrm{CF}=\mathrm{Base}+$ cover; $\mathrm{BF}+\mathrm{BI}=\mathrm{Base}$ Fertilization + Inoculation; $\mathrm{BF}+\mathrm{BI}+\mathrm{CF}=\mathrm{Base}+$ cover fertilization + Inoculation; $\mathrm{BI}=\mathrm{Inoculation} ; \mathrm{BI}+\mathrm{CF}$ $=$ Inoculation + cover fertilization; NFI = no fertilization or inoculation; FC = cover fertilization.

crop yield, thereby corroborating the studies carried out by Cavallet et al. (2000) and Brum et al. (2016).

When it comes to the number of rows per ear (Table 3 ), the $\mathrm{BF}+\mathrm{CF}$ and $\mathrm{BI}+\mathrm{CF}$ treatments presented the ears with the highest number of rows with values greater than 13 rows per ear, being significantly different from the other treatments. These results indicate that top cover cultivation shows positive results, regardless of the form of base fertilization or inoculation. Similar results were found by Müller et al. (2016), who found positive results when they combined inoculation methods with the application of mineral nitrogen as coverage.

The treatments which only applied nitrogen on the top or nitrogen cover fertilization + Inoculation $(\mathrm{BF}+\mathrm{CF}, \mathrm{BF}+\mathrm{BI}+\mathrm{CF}$, and $\mathrm{BI}+\mathrm{CF}$ ) obtained higher results when compared to the other treatments (BF+BI, BI, and $\mathrm{NFI}$ ) in terms of thousandgrain weight (Table 3 ). This result was also found by Brum et al. (2016), who observed an increase in grain weight when using $A$. brasilense when compared to non-inoculation tests. Kappes et al. (2013) reported that grain mass is influenced by genotype, nutrient availability, and climatic conditions during the grain filling stage.

Maize yield was influenced by fertilization management (Table 3) as the $\mathrm{BF}+\mathrm{CF}, \mathrm{BF}+\mathrm{BI}+\mathrm{CF}$, and $\mathrm{BI}+\mathrm{CF}$ productive treatments significantly differed from the others. The lowest yield was observed in the control treatment (NFI). However, the $\mathrm{NFI}$ test showed lower values than the BF+BI and BI treatments, showing the effect of fertilization on corn yield. Once more, high values were observed in the $\mathrm{BI}+\mathrm{CF}$ treatment, indicating that inoculation associated with cover fertilization may be an attractive alternative for producers. In this sense, we can note that inoculation is sufficient to supply the nitrogen applied at the base. However, it was not able to provide adequate nutrient demand, similar to the cover fertilization. This can be associated with the high nitrogen demand by the corn crop and its enormous response, particularly when subjected to the mineral nitrogen fertilization.

The data are in agreement with those found by Brum et al. (2016), who observed that the control (without nitrogen fertilization or bacterial inoculation) was the least productive treatment when compared to the treatments with nitrogen fertilization and $A$. brasilense bacteria inoculation. The treatment with microorganisms produced approximately 330 $\mathrm{kg} \mathrm{ha}^{-1}$, with similar results to Müller et al. (2016). However, these authors observed a gain of $567 \mathrm{~kg} \mathrm{ha}^{-1}$ when compared to inoculated and non-inoculated treatments.

In the second crop year, yield components such as ear length, number of rows per ear, and thousand-grain weight were also influenced by the treatments (Table 3). Ear length was influenced by nitrogen fertilization and the $A$. brasilense inoculation $(\mathrm{BF}+\mathrm{CF}, \mathrm{BF}+\mathrm{BI}, \mathrm{BF}+\mathrm{BI}+\mathrm{CF}$, and $\mathrm{BI}+\mathrm{CF})$. They were also significantly longer than treatments which did not receive nitrogen fertilization ( $\mathrm{BI}$ and $\mathrm{NFI}$ ) or only cover fertilization (CF). However, it was observed that the $\mathrm{BI}$ treatment performed significantly different from the CF and NFI treatments, clearing the effect of inoculation.

Nitrogen base fertilization was significant when associated with the cover fertilization methodology. This observation is supported by the number of rows per ear, as the BF+CF and $\mathrm{BF}+\mathrm{BI}+\mathrm{CF}$ treatments accounted for the highest values. Although it was significantly different from the others, the treatments which had inoculation with the addition of nitrogen $(\mathrm{BF}+\mathrm{BI}$ and $\mathrm{BI}+\mathrm{CF})$ were superior to treatments that did not receive nitrogen ( $\mathrm{NFI}$ ) or only received nitrogen in the coverage (CF), or nitrogen as inoculation (BI). Therefore, we are able to claim that inoculation is effective when used as a kind of complementary nitrogen (base or cover). This significant increase in the number of rows influenced the higher yield of grains per ear, leading to increased productivity 
in the treatments which were inoculated (Table 3). A relevant argument is that due to the extreme complexity of soil nitrogen dynamics, which is strongly influenced by environmental variables, the use of nitrogen top cover fertilization typically increases maize crop yield (Coelho et al., 2018).

There was a significant difference between treatments for the thousand grain weight component with the application of nitrogen combined or not with $A$. brasilense $(\mathrm{BF}+\mathrm{CF}, \mathrm{BF}+\mathrm{BI}+\mathrm{CF}$, $\mathrm{BI}+\mathrm{CF})$ compared to the others $(\mathrm{BF}+\mathrm{BI}, \mathrm{BI}, \mathrm{NFI}$, and $\mathrm{CF})$ (Table $3)$. The thousand-grain weight is a valuable parameter since it is possible to obtain higher productivity increasing the accumulated reserves in the grains from the same number of the fertilized ovule (Santini et al., 2018). This was observed when we used nitrogen in at least two associated forms $(\mathrm{BF}+\mathrm{CF}, \mathrm{BF}+\mathrm{BI}+\mathrm{CF}$, or $\mathrm{BI}+\mathrm{CF})$. However, nitrogen usage was lower when we applied the single form, leading to lower productivity in the $\mathrm{BF}+\mathrm{BI}, \mathrm{BI}, \mathrm{NFI}$, and $\mathrm{CF}$ treatments. Martins et al. (2018), evaluated inoculation efficiency and different nitrogen application methods and obtained an increase of $10.78 \%$ in popcorn yield apart from reduced cover fertilization to $50 \mathrm{~kg} \mathrm{ha}^{-1}$ in the presence of $A$. brasiliense.

It is noteworthy that we obtained higher production using only inoculation (BI) compared to the test accomplished in the absence of nitrogen sources (NFI) (Table 3 ). This result highlights the efficiency of inoculation, even when it is not combined with another nitrogen source. Comparatively, Martins et al. (2018) obtained an increase of $25.49 \%$ in the yield of popcorn when compared to the treatment without $\mathrm{N}$ addition and $A$. brasiliense inoculation application. The test using inoculation in our study accounted for $31.8 \%$ higher yields than the cultivation of corn without nitrogen. However, producers must also consider the mineral nitrogen fertilization to reach maximum crop potential. Studies by Müller et al. (2016) found an increase in corn yield when inoculating with $A$. brasilense, regardless of the inoculation method (furrow or seeds) or the use of cover nitrogen. On the other hand, Mascarello \& Zanão Júnior (2015) verified that seed inoculation with $A$. brasilense did not influence yield. The authors studied maize yield as a function of nitrogen dosage in cover associated or not with $A$. brasilense seed inoculation.

Regarding the leaf nitrogen content (Table 4), the treatments that received nitrogen cover fertilization ( $\mathrm{BF}+\mathrm{CF}$, $\mathrm{BF}+\mathrm{BI}+\mathrm{CF}$, and $\mathrm{BI}+\mathrm{CF})$ presented the highest contents compared to the other treatments $(\mathrm{BF}+\mathrm{BI}, \mathrm{BI}$, and $\mathrm{NFI})$. The higher nitrogen content in the leaves provides increased plant growth and development, and can contribute to a more significant nitrogen concentration in the grain (Santini et al., 2018). In this sense, the use of bacteria as a nitrogen source can influence a partial reduction of mineral fertilizer, as observed by Araújo et al. (2014). However, according to Pereira et al. (2015), the inoculation effect should be carefully analysed, as the inoculation response is intrinsic to each genotype used and cannot be employed as a general rule.

Thus, we highlight that plants with higher leaf nitrogen content grow and develop better. It provides a higher leaf
Table 4. Leaf nitrogen $\left(\mathrm{g} \mathrm{kg}^{-1}\right)$ and grain nitrogen $\left(\mathrm{g} \mathrm{kg}^{-1}\right)$ in response to seed inoculation with Azospirillum brasilense, and nitrogen fertilization at sowing and cover.

\begin{tabular}{cccc}
\hline \multirow{2}{*}{ Treatments } & \multicolumn{2}{c}{ First crop year } & Second crop year \\
\cline { 2 - 4 } & $\begin{array}{c}\text { Leaf } \\
\text { nitrogen }\end{array}$ & $\begin{array}{c}\text { Nitrogen } \\
\text { grain }\end{array}$ & $\begin{array}{c}\text { Nitrogen } \\
\text { grain }\end{array}$ \\
\cline { 2 - 4 } & \multicolumn{3}{c}{$\left(\mathrm{g} \mathrm{kg}^{-1}\right)$} \\
\hline $\mathrm{BF}+\mathrm{CF}$ & $19.46 \mathrm{a}$ & $10.32 \mathrm{a}$ & $11.17 \mathrm{a}$ \\
$\mathrm{BF}+\mathrm{BI}$ & $14.86 \mathrm{~b}$ & $9.01 \mathrm{a}$ & $10.29 \mathrm{a}$ \\
$\mathrm{BF}+\mathrm{BI}+\mathrm{CF}$ & $20.70 \mathrm{a}$ & $10.22 \mathrm{a}$ & $11.31 \mathrm{a}$ \\
$\mathrm{BI}$ & $17.40 \mathrm{~b}$ & $10.05 \mathrm{a}$ & $9.38 \mathrm{~b}$ \\
$\mathrm{BI}+\mathrm{CF}$ & $20.46 \mathrm{a}$ & $9.62 \mathrm{a}$ & $11.06 \mathrm{a}$ \\
$\mathrm{NFI}$ & $16.64 \mathrm{~b}$ & $8.78 \mathrm{a}$ & $9.38 \mathrm{~b}$ \\
$\mathrm{CF}$ & - & - & $8.44 \mathrm{~b}$ \\
$\mathrm{CV}(\%)$ & 11.28 & 12.72 & 7.76 \\
\hline
\end{tabular}

* Means followed by the same letter on the line do not differ from each other by the Scott-Knott test at $5 \%$ probability. First crop year: $\mathrm{BF}+\mathrm{CF}=\mathrm{Base}+$ cover; $\mathrm{BF}+\mathrm{BI}=$ Base Fertilization + Inoculation; $\mathrm{BF}+\mathrm{BI}+\mathrm{CF}=\mathrm{Base}+$ cover fertilization + Inoculation; $\mathrm{BI}$ $=$ Inoculation; $\mathrm{BI}+\mathrm{CF}=$ Inoculation + Cover fertilization; $\mathrm{NFI}=$ no fertilization or inoculation; $\mathrm{CF}=$ Cover fertilization.

area index and consequently high carbohydrate synthesis by photosynthesis. These aspects will enhance the root system development which could take major advantage of the nitrogen in the soil or the fertilizer (Araújo et al., 2014).

In comparing the $\mathrm{N}$ content values in the grains, it is observed that no significant differences were observed between the treatments in the first crop year (Table 4). However, in the second crop year it was verified that most of the accumulated nitrogen mainly originated from the treatments with conjugated nitrogen application $(B F+C F$, $B F+B I, B F+B I+C F$, and $B I+C F)$, showing a positive effect of the use of nitrogen in different forms and application times.

Similar results were obtained by Skonieski et al. (2019), as they observed that only part of the nitrogen required by the maize crop is supplied by the Azospirillum ssp bacterium . In this case, it was necessary to complement the mineral fertilization of nitrogen. This fact occurred because the crop has a great response to the use of nitrogen, and it is one of the essential nutrients for increasing productivity (Chalk, 2016).

\section{Conclusion}

The use of nitrogen in the base or cover fertilization showed significant results in terms of productivity increment when used together or combined with inoculation. Moreover, the use of inoculant in association with nitrogen cover fertilization showed positive results when compared to the use of nitrogen only in coverage. Finally, the $A$. brasilense bacterium promoted an increase in productivity when associated with nitrogen fertilization.

\section{Literature Cited}

Alvares, C.A.; Stape, J.L.; Sentelhas, P.C.; Goncalves, J.L.M.; Sparovek, G. Köppen's climate classification map for Brazil. Meteorologische Zeitschrift, v.22, n.6, p.711-728. 2013. https:// doi.org/10.1127/0941-2948/2013/0507. 
Araújo, R. M.; Araújo, S. F.; Nunes, L. A. P. L.; Figueiredo, M. V. B. Resposta do milho verde à inoculação com Azospirillum brasilense e níveis de nitrogênio. Ciência Rural, v. 44, n. 9, p. 1556-1560, 2014. https://doi.org/10.1590/0103-8478cr20130355.

Brum, M. S.; Cunha, V. S.; Stecca, J. D. L. Grando, F. T.; Martin, T. N. Components of corn crop yield under inoculation with Azospirillum brasilense using integrated crop-livestock system. Acta Scientiarum. Agronomy, v.38 n. 4, p. 485-492, 2016. https:// doi.org/10.4025/actasciagron.v38i4.30664.

Bulegon, L. G.; Guimarães, V. F.; Inagaki, A. M.; Battistus, A. G.; Offemann, L. C.; Souza, A. K. Pomini de. Respostas da soja ao Azospirillum brasilense e reguladores vegetais em condições de déficit hídrico. Revista Brasileira de Ciências Agrárias, v.14, n.4, p. 1-10, 2019. https://doi.org/10.5039/agraria.v14i4a5678.

Cavallet, L. E.; Pessoa, A. C. Dos S.; Helmich, J.J.; Helmich, P. R.; Ost, C. F. Produtividade do milho em resposta à aplicação de nitrogênio $e$ inoculação das sementes com Azospirillum spp. Revista Brasileira de Engenharia Agrícola e Ambiental, v.4, n.1, p.129-132, 2000. https://doi.org/10.1590/S1415-43662000000100024.

Chalk, P. M. The strategic role of ${ }^{15} \mathrm{~N}$ in quantifying the contribution of endophytic $\mathrm{N}_{2}$ fixation to the $\mathrm{N}$ nutrition of non-legumes. Symbiosis, v. 69, n. 2, p. 63-80, 2016. https://doi.org/10.1007\%2 Fs13199-016-0397-8.

Coelho, B. A.; Dias, V. C.; Pelúzio, J. M.; Souza, C. M.; Siqueira, G. B.; Santos, W. F. Productivity of the corn cultivated under low latitude in the inter-crop inoculated with Azospirillum brasilense with diferent doses of nitrogen. Journal of Bioenergy and Food Science, v.6, n.1, p. 18-28, 2018. https://doi.org/10.18067/jbfs. v6i1.255.

Comissão de Química e Fertilidade do Solo - RS/SC. Sociedade Brasileira de Ciência do Solo. Manual adubação e de calagem para os estados do Rio Grande do Sul e de Santa Catarina. 10.ed. Porto Alegre: Sociedade Brasileira de Ciência do Solo; Núcleo Regional Sul; Comissão de Química e Fertilidade do Solo - RS/ SC, 2004. 400p

Companhia Nacional de Abastecimento - Conab. Perspectivas para a agropecuária - Safra 2018/2019. Brasília: Conab, 2018. v.6, 112p. https://www.conab.gov.br/perspectivas-para-a-agropecuaria/ item/download/22780_ee707c6e6d44f06fe7b6a86ce6141652. 19 Dez. 2019.

Fukami, J.; Ollero, F. J.; Osa, C.; Valderrama-Fernández, R.; Nogueira, M. A.; Megías, M.; Hungria, M. Antioxidant activity and induction of mechanisms of resistance to stresses related to the inoculation with Azospirillum brasilense. Archives of Microbiology, v.200, p. 1191-1203, 2018. https://doi. org/10.1007/s00203-018-1535-x.

Hungria, M., Campo, R. J., Souza, E. M.; Pedrosa, F. O. Inoculation with selected strains of Azospirillum brasilense and $A$. lipoferum improves yields of maize and wheat in Brazil. Plant and Soil, v,331, 413-425, 2010. https://doi.org/10.1007/s11104-009-0262-0.

Kappes, C.; Arf, O.; Arf, M. V.; Ferreira, J. P.; Dal Bem, E. A.; Portugal, J. R.; Vilela, R. G. Seeds inoculation with diazotrophic bacteria and nitrogen application in side-dressing and leaf in maize. Semina: Ciências Agrárias, v. 34, n. 2, p. 527-538, 2013. https://doi. org/10.5433/1679-0359.2013v34n2p527.
Ladha, J. K.; Tirol-Padre, A.; Reddy, C. K.; Cassman, K. G.; Verma, S.; Powlson, D. S.; Van-Kessel, C.; Richter, D. B.; Chakraborty, D.; Pathak, $\mathrm{H}$. Global nitrogen budgets in cereals: A 50-year assessment for maize, rice, and wheat production systems. Scientific Reports. v.6, n.19355, p. 1-9, 2016. https://doi.org/10.1038/srep19355.

Martins, T. G.; Freitas Júnior, S. P.; Luz, L. N.; Marco, C. A.; Vásquez, E. M. F. Inoculation efficiency of Azospirillum brasilense on economising nitrogen fertiliser in landrace popcorn. Revista Ciência Agronômica, v. 49, n. 2, p. 283-290, 2018. https://doi. org/10.5935/1806-6690.20180032.

Mascarello, G.; Zanão Júnior, L. A. Produtividade de milho em resposta a doses de nitrogênio e inoculação das sementes com Azospirillum brasilense. Revista Cultivando o Saber, edição especial, p. 46-55, 2015. https://www.fag.edu.br/upload/revista/ cultivando_o_saber/566ec3b5143a2.pdf. 19 Dez. 2019.

Müller, T. M.; Sandini, I. E.; Rodrigues, J. D.; Novakowiski, J. H.; Basi, S.; Kaminski, T. H. Combination of inoculation methods of Azospirillum brasilense with broadcasting of nitrogen fertilizer increases corn yield. Ciência Rural, v. 46, n. 2, p. 210-215, 2016. https://doi.org/10.1590/0103-8478cr20131283.

Pereira, L. M.; Pereira, E. M.; Revolti, L. T. M.; Zingaretti, S. M.; Môro, G. V. Seed quality, chlorophyll contente index and leaf nitrogen levels in maize inoculated with Azospirilum brasilense. Revista Ciência Agronômica, v. 46, n. 3, p. 630-637, 2015. https://doi. org/10.5935/1806-6690.20150047.

Picazevicz, A. A. C.; Kusdra, J. F. and Moreno, A. de L.. Maize growth in response to Azospirillum brasilense, Rhizobium tropici, molybdenum and nitrogen. Revista Brasileira de Engenharia Agrícola e Ambiental. v.21, n.9, p-623-627. 2017. https://doi. org/10.1590/1807-1929/agriambi.v21n9p623-627.

R Core Team. R: A language and environment for statistical computing. Vienna: R Foundation for Statistical Computing, 2019. https:// www.R-project.org. 19 Dez. 2019.

Santini, J. M. K.; Buzetti, S.; Teixeira Filho, M. C. M.; Galindo, F. S.; Coaguila, D. N.; Boleta, E. H. M. Doses and forms of Azospirillum brasilense inoculation on maize crop. Revista Brasileira de Engenharia Agrícola e Ambiental, v. 22, n. 6, p.373-377, 2018. https://doi.org/10.1590/1807-1929/agriambi.v22n6p373-377.

Santos, H. G. dos; Jacomine, P. K. T.; Anjos, L. H. C. dos; Oliveira, V. A. de; Lumbreras, J. F.; Coelho, M. R.; Almeida, J. A. De; Araújo Filho, J. C. de; Oliveira, J. B. de; Cunha, T. J. F. Sistema brasileiro de classificação de solos. 5.ed. Brasília: Embrapa, 2018. http://ainfo. cnptia.embrapa.br/digital/bitstream/item/181677/1/SiBCS2018-ISBN-9788570358172.epub. 07 Dez. 2019.

Skonieski, F. R.; Viégas, J.; Martin, T. N.; Mingotti, C. A. C.; Naetzold, S.; Tonin, T. J.; Dotto, L. R.; Meinerz, G. R. Effect of nitrogen topdressing fertilization and inoculation of seeds with Azospirillum brasilense on corn yield and agronomic characteristics. Agronomy, v. 9, n. 812, p- 1-11, 2019. https://doi.org/10.3390/agronomy9120812.

Tedesco, M. J.; Gianello, C.; Bissani, C. A.; Bohnen, H.; Volkweiss, S. J. Análises e solo, plantas e outros materiais. 2.ed. Porto Alegre: UFRGS; Departamento de Solos, 1995. 174p. (Boletim Técnico de Solos. UFRGS. Departamento de Solos, 5).

United States Department of Agriculture - USDA. World agricultural supply and demand estimates. Washington: USDA, 2019. 40p. https://www.operefuturos.com.br/wp-content/ uploads/2019/02/wasde-08-01-2019.pdf. 19 Dez. 2019. 